\title{
Flexible Activities of the Organization in Implementation of the Sustainable Development Principles in Selected Areas of the Organizations
}

\author{
Eng. Anna Lemańska-Majdzik, Ph.D. ${ }^{1}$
}

\begin{abstract}
Flexible activities of the organization result from changes in the market environment. However, the multidimensionality of the concept of flexibility of actions leads to considerations in the field of organizational behavior from the perspective of business management. The aim of the paper is to compare flexible activities of companies in the implementation of sustainable development principles in selected areas of ongoing activities. The research in the form of case study was conducted at the turn of 2017 and 2018 on the basis of the interview questionnaire. The inference is based on the results of own research on selected organizations: profit and nonprofit, which declared the implementation of sustainable development principles in their current operations. The conducted research allowed to compare the activities aimed at introducing the above-mentioned principles in the selected areas of organiations' activities. Since the main objectives of the organizations' activities are assumed to be different, the desire to implement the principles of sustainable development may result not only from the main goals of the company, but also from changes in the business environment, customer expectations and from sustainable developmentoriented leadership.
\end{abstract}

Keywords: Flexibility activities, principles of sustainable development, business management, profit and nonprofit organizations

\section{Introduction}

An organisation's flexible actions result from changes in its market and business environments, but the multidimensional character of flexibility prompts reflection on organisational behaviour from the perspective of management of an organisation. The concept of sustainable development, which is implemented by enterprises and non-profit organisations, leads to balancing of organisations' economic goals with environmental and social ones. In the age of globalisation, environmental and social aspects are increasingly important in the process of management. This is due to the expectations and needs of the stakeholders shaping the future of organisations. Annan-Diab and Molinari (2017) stress that it is necessary to propagate the principles of sustainable development in all areas of life, and due to the interdisciplinary character of this concept, it should also be considered in the field of management and organisational education.

The aim of the paper is to compare flexible actions of organisations in implementing the principles of sustainable development in selected areas of ongoing activities. The research, which was conducted in the end of 2017 and in the beginning of 2018 in 
Poland using the case study method, involved two organisations, one for-profit and one non-profit, declaring the implementation of the principles of sustainable development in their activities.

\section{Literature Review - Principles of Sustainable Development in Flexible Activities of Organisations}

Nowadays, organisations significantly contribute to sustainable development of societies, which is also visible in ongoing activities of enterprises. However, the issue of sustainable development at the level of an enterprise is much broader than environmental aspects connected with economic activity (Dvořáková, \& Zborková, 2014; Baumgartner, \& Rauter, 2017). An organisation wishing to respond to the challenges posed by sustainable development should address all aspects, including social ones, in its activities. Balancing an organisation's economic goals with environmental and social goals is not an easy task. Taking actions in line with the concept of sustainability requires appropriate approach of the managerial staff and attitudes of employees (Trojanowski, 2015), as well as appropriate strategies for long-term action.

External factors determining a company's integration with the principles of sustainable development include, among other things, organisational reputation, customers' demand for transparency, regulation, social awareness, access to resources and cooperation with external entities. Among the internal factors driving sustainable development are, among other things, capability of active leadership, arguments in favour of change, the principle of caution to prevent harm to the environment, corporate culture, moral obligations, sustainable development reporting and risk avoidance (Lozano, 2015).

Review of the literature shows that organisations should implement sustainable development (SD) rather than concentrate only on profit. Enhanced performance of economic entities should be assessed not only in terms of the value of services, manufactured products and profits, but also in terms of the impact on human and social aspects. However to achieve that, organisations need to change the traditional way of thinking and be flexible in their activities. A special role is played here by stakeholders, who expect much more from organisations than achievement of the basic goals. The concept of sustainable development can be promoted in an organisation through social responsibility and a number of available instruments such as: quality management systems, environmental management systems, systems for management of occupational safety and health, organic production, appropriate care, social support, etc. (Hyršlová, 2009). Thus, a company's success and performance assessment have to involve, apart from the standard financial indicators, important non-financial aspects, which represent the ability to combine economic, environmental and social aspects, and demonstration of results in these area (Dvořáková, \& Zborková, 2014). Organisations have started to be aware of the importance of the balance between economic, environmental and social priorities in various areas of ongoing activities (Nawaz, \& Koç, 2018). To preserve growth, organisations implement the principles of sustainable development through: business processes, including cooperation with suppliers, customers and local communities, production planning and execution, marketing and sale of products. This, undoubtedly, impacts relationships with their environment. 
Systematic global studies on the implementation of sustainable development principles show that this problem is recognised by managers and the results in various organisations become more optimistic each year (Sroufe, 2017). According to the research presented by McKinsey Global Survey (2014), almost 60\% of managers declared that sustainable development had been integrated with their corporate culture, but only under $40 \%$ stated that it was a factor impacting performance management in the organisation. Studies of MIT Sloan Management Review and The Boston Consulting Group (2017) show that $90 \%$ of the managerial staff perceive sustainable development as an important issue, but only $60 \%$ of companies have a sustainable development strategy in place (Kiron, Unruh, Kruschwitz, Reeves, Rubel, \& Meyer Zum Felde, 2017). Enterprises recognise the contribution of their activities to sustainable development, but small and medium-sized businesses are unable to do so or do not see the need to introduce this concept into strategic management or strategic goals of their organisations. This may be due to failure to understand the benefits of sustainable development to economic results. Organisations simply focus on economic results. In such cases, expenditures that are required to implement sustainable development principles seem unnecessary against the economic benefits of this concept. The main problem is to take into account social aspects in the assessment of a company's performance with respect to financial criteria, especially in terms of economic benefits (Dvořáková, \& Zborková, 2014). Not all organisations can afford to comply rigorously with the principles of sustainable development, but all should attempt to implement this idea, at least in selected areas of their activities.

An organisation's integrated activities to implement sustainable development are in conflict with the standards set by the process of globalisation. The basic reason is flexibility. It applies to the problem of free movement of capital, in particular. Flexibility, considered from the perspective of demand, is in an open conflict with the postulate of sustainable development, because it allows for migration of capital towards areas that provide better conditions for growth, which mainly fulfils the requirement of cost efficiency (Brzozowski, 2010). The practices of the implementation of sustainable development principles may be very expensive, but, as the 2016 report Carbon Disclosure Project shows, in the long term the number of such practices is greater in organisations which have sustainable development included in their basic business strategy (Melkonyan, Gottschalk, \& Vasanth Kamath, 2017).

Studies byLindof, Kaluza and Stark (2018) on a group of small and medium-sized businesses revealed a range of cultural practices that comprise SD-oriented culture and showed sustainable development-oriented leadership. It was also found that the key is continuous education and awareness raising using both top-down and bottom-up communication as well as shared responsibility and accountability across the whole organisational structure. Thus, it was not only the managerial staff that assumed responsibility for the implementation of this concept. Some industry practitioners believed that sustainable development might become a priority for employees if it is embedded in specific strategic goals that impact key indicators of employees' performance.

Thus, flexibility in terms of an organisation's strategy of action may create some benefits for an organisation. Economic entities with strategic flexibility usually manage economic 
risk in an effective way, proactively responding to market threats and opportunities (Ussahawanitchakit, \& Sriboonlue, 2011). The term "strategic flexibility" does not have a commonly accepted definition; according to (Snachez, 1995), strategic flexibility involves an organisation's ability to respond fast to opportunities and changes in its environment. According to Bhandari at al. (2004), the concept of strategic flexibility allows an organisation to be able to develop new products and enter new markets or new industries. Katsuhiko and Hitt (2004) defined strategic flexibility as an organisation's capability to identify changes in its external environment and to respond fast to them. Roberts and Stockport (2009) described strategic flexibility as a way that allows organisations to achieve a greater success, which suggests that organisations select, develop and adjust strategic choices to keep up with the constantly changing business environment (Ivanová, Lemańska-Majdzik, 2017.

Strategic flexibility is a critical organisational competence that makes companies more active. Therefore flexible companies can analyse changes in their environment. This allows them to take advantage of the opportunities created by dynamic conditions (Cingöz, Akdoğan, 2013). What is more, strategic flexibility is necessary for the development of a company. Long-term growth is supported by a continuous process of finding new sources and capabilities generating competition of benefits (Tamayo-Torres and colleges, 2010; Sipa, 2017).

An interesting idea is to compare a non-profit organisation with a for-profit organisation, two types of organisations whose ideas of existence are poles apart. Both these types are guided by the laws of economic profit, but in completely different forms. As stressed by Seidel at al. (2008), the key research challenge is to find an answer to the question: How should organisations embed sustainable business practices in their basic business activities? This issue is especially important in the case of the biggest group of companies, i.e. small and medium-sized businesses. Entrepreneurs managing small and medium-sized businesses do not realize that their activities impact the natural and social environment (Oliveira Neto et al., 2017). Study of the non-profit sector (Avsec, \& Stromajer, 2015), which is very diverse in terms of the objectives of activity and provided services, may also become an interesting area.

The process of defining a sustainable development strategy needs to take into account each type of stakeholder in order to be really sustainable. Therefore, it is very important for an enterprise to gain an initial knowledge of its environment, and identify the actual stakeholders and define itself with respect to the key ones (Brzozowski, 2010). In the case of housing cooperatives (non-profit organisations), the key stakeholders are the residents, who on the one hand expect efficient management of their real estate (Lemańska-Majdzik, 2013), while on the other hand - understanding of their day-to-day needs. Research by Purtik, Zimmerling and Welpe (2016) shows that housing cooperatives are a good place to implement the principles of sustainable development with engagement on the part of residents. For a medium-sized manufacturing enterprise with a very good market position, the key stakeholders are its customers, who demand highest quality goods, manufactured in accordance with the existing standards, as well as its employees, who expect that the enterprise's owners provide financial benefits and support in difficult social situations. 


\section{Research Methodology}

The aim of the paper is to compare organisations' flexible actions in the implementation of sustainable development principles in selected areas of ongoing activities.

The research using the method of case study was conducted in the beginning of 2017 and in the end of 2018 based on an interview questionnaire. The research covered one non-profit organisation, which is one of the largest housing cooperatives in the region, and one for-profit organisation, which is a family-run manufacturing company classified as a medium-sized business according to the number of employees. At the request of the respondents, the non-profit organisation was called $\mathrm{X}$, and the for-profit organisation was referred to as $\mathrm{Y}$. The direct interview was conducted with managers of/persons managing the organisations researched (Chairman of the Management Board of the Housing Cooperative and the owner of the manufacturing company) using the author's own questionnaire, which mostly consisted of open-ended questions, which allowed the respondents to express their opinions based on a set of questions.

The research sample was purposive, and based on the size, attractiveness and dynamic development of the organisations. Both the organisations interviewed are business leaders in their respective areas of fundamental activity, not only in their regions, but also in Poland, which is confirmed by numerous awards and recognitions received by them. The conclusions were made on the basis of the findings of the author's own study of two organisations: a for-profit organisation and a non-profit organisation, which declared the implementation of the principles of sustainable development in their ongoing activities. The research's author was interested in the activities outside of the main goals of the organisations' activity. An attempt was made to analyse those areas of the implementation of SD which are not obligatory, but result from flexibility of organisations' actions and from SD-oriented leadership, as was found out later.

The research is a preliminary study, which can be used to further investigate the problem in the future by conducting research on a bigger research group, as well as to verify a research tool for further extended studies.

\section{Characterisation of the Organisations Researched and Findings of the Case Study Research}

\subsection{Non-profit Organisation}

The first organisation subjected to analysis was a non-profit organisation, a housing cooperative. According to the Polish law, a cooperative is a voluntary association of persons, with varying equity fund and varying membership, that engages in a joint economic activity for the benefit of its members. A housing cooperative as a nonprofit organisation can be interested in income, as every organisation, but the income has to be spent in accordance with the provisions in its statute (Cooperative law, 1982). Generally, a cooperative can carry on social and educational and cultural activity for the benefit of its members and their community. A housing cooperative can carry on economic activity, but it cannot bring profits to its members (it cannot derive financial benefits at the cost of its members, especially from transformations of rights to 
premises). The fact that a given organisation does not operate for profit is stated in the statute of the cooperative. In accordance with art. 1 of the Act of 15 December 2000 on housing cooperatives, the objective of a housing cooperative is mainly to meet housing and other needs by providing its members with self-contained residential units or singlefamily homes, as well as non-residential premises. A housing cooperative differs from a for-profit organisation in that the objective of management of a housing cooperative is to achieve balance between the income and costs of operation, rather than a profit.

The non-profit organisation participating in the research was Housing Cooperative X, which has been operating in Silesian Voivodeship, in Poland, since 1978. The housing resources of Housing Cooperative $\mathrm{X}$ are situated in the northern district of the city and constitute a uniform, isolated urban layout with the area of 99 ha and $4238 \mathrm{~m}^{2}$. It is one of the largest housing cooperatives in the region, as currently its total usable area is 505,763.18 $\mathrm{m}^{2}$. As of 31 December, 2017, Housing Cooperative X possesses 9166 residential units, and its housing resources include: 30 commercial buildings, including 3 tenants' associations, 144 residential buildings, 124 garages, and 12 garages situated in a residential building.

According to the statute of the Housing Cooperative, it was established to operate the real estate on its own account, manage real estates based on order, purchase and sell real estates on its own account, use and sell real estates on its own account, rent real estates on its own account, and conduct activity connected with culture, recreation and sport. Housing Cooperative X can carry on other economic activity independently or with other enterprises, following the principles of economic balance, if this is in line with the objectives defined in the organisation's statute. Moreover, the organisation in question can participate in cooperation with other organisations to achieve the objectives set down in the organisation's statute.

The interview shows that effective management of the housing cooperative's resources is, according to the respondent, perceived from the perspective of residents, i.e. the organisation's customers. This is because the main objective of the organisation's activity is to meet their needs (mainly housing needs). Moreover, the respondent indicated that management should be flexible, because by adapting to the conditions of the environment and customers' needs, the Housing Cooperative would be able to achieve its main objective. Effective management of the cooperative resources also means taking actions aimed at improving the living standard of residents and the Cooperative's image. The concept of sustainable development is understood by the respondent according to the following definition: "Sustainable development (SD) is a socio-economic development where in order to balance the chances of access to the environment for the different societies or their citizens - both the current one and that of future generations - political, economic and social activities are integrated whilst keeping natural balance and durability of basic natural processes." However, as the respondent stresses, the concept of SD is not mentioned in the statute of Housing Cooperative X.

Based on the interview, the activities of the organisation researched can be divided into three groups:

1) Activities related to the operation of the real estate, which result from the managerial role fulfilled by the organisation, as well as from additional activities undertaken independently, which are not obligatory for this type of an organisation. Notably, the 
organisation made significant investments connected with the environmental protection, energy-efficient construction and to improve the life of the residents. Most activities of the Cooperative result from the existing legal regulations and are undertaken as part of its basic scope of activity. However, examples of additional activities falling under the principles of sustainable development include:

- implementation of water meters with remote reading in all housing units,

- implementation of new generation heat cost allocators with remote reading,

- LED lighting in staircases, corridors and basement corridors with motion detectors (activity completed in 70\%),

- replacement of windows in staircases and basement windows with new, plastic windows as part of energy-efficient renovation (in housing units, this investment covers almost 95\%),

- commencement of the construction of own fibre-optic network in FTTH technology fibre to the home.

- arrangement of a full offer of TVK cable television for the Cooperative's residents, with over $70 \%$ of channels broadcast in HD quality.

2) The social and educational activity resulting from the Cooperative's statute, as well as additional actions related to the implementation of sustainable development principles, includes social support. On the premises of the Cooperative, there are two community clubs offering activities for children, youth and adults, and events called "Summer" and "Winter" are organised. These are however typical activities undertaken by housing cooperatives. It is worth mentioning activities that are not common, according to the respondent, across similar organisations on the market, which include:

- providing funding and premises for two Pensioners' Clubs,

- supporting the Senior Citizens' Club as part of the national Support Campaign for Senior Citizens,

- care of a scout team,

- care of the Polish Fishing Association Club,

- creating and running a model making workshop for children and youth, which offers cyclical free activities for the residents,

- publishing a free quarterly "News from the North",

3) Environmental protection, including development of green areas. This area of activities of the organisation researched is its priority, because, as the respondent declares, Housing Cooperative X possesses the most visually attractive and effectively developed green areas. It is worth adding that on the premises of the Cooperative, there are three internal parks with full sports and recreational infrastructure for children, youth and adults. Moreover, any changes (e.g. planting and removal of trees) in green areas are consulted with a relevant unit of Częstochowa local authority (in accordance with the existing legal regulations) and with the residents (which is not obligatory).

\subsection{For-profit Organisation}

The second organisation covered by the research was a for-profit organisation, a family-run business engaged in the production of multi-purpose trolleys, pushchairs, 
children's car seats and various accessories at the international scale. The business is located in Czestochowa, in Poland, and was established in 1970. In 2000, Company Y expanded its range of products, introducing new brands under the basic name. The company is a leader on the Polish market, its products received numerous recognitions and awards from customers and the community connected with the manufacturing of pushchairs. The company's objectives are achieved by adapting to customer needs and implementing innovative solutions in broadly understood production technology.

Company $\mathrm{Y}$ operates based on an adopted organisational structure, but it lacks organisation chart that clearly shows relationship and reporting lines. This may be due to the fact that it is a business firmly embedded in a family. Currently, the company is managed by two generations (first degree relationship). A characteristic feature of this company is passing on expertise from generation to generation, and at the same time lack of managerial education of family members at managerial posts. As a result of fast growth (over the last 5 years), the company currently employs almost 150 people, and is classified as a medium-sized company by the number of employees. The company sells its products through wholesalers and its own store. It sells most of its products abroad, declaring that its export to European and Asian markets accounts for almost $70 \%$ of the total sale. Apart from that, the company provides post-sale and maintenance services.

The interview shows that the idea of sustainable development is known to the respondent, and he declares that it is stated in the vision of company Y. However, it can be seen based on the interview, that the respondent is not aware of the implementation of SD principles in the company's ongoing activities.

The respondent from organisation $\mathrm{Y}$ understands the concept of sustainable development according to the following definition: "Sustainable development (SD) is a socioeconomic development where in order to balance the chances of access to the environment for the different societies or their citizens - both the current one and that of future generations - political, economic and social activities are integrated whilst keeping natural balance and durability of basic natural processes."

Based on the interview, the activities of the organisation researched can be divided into two groups:

1) Activities related to the development of its basic scope of activity, i.e. production of multi-purpose trolleys, pushchairs, children's car seats and various related accessories. In this case, the organisation implements obligatory quality standards and the latest technologies used in the industry. The respondent did not indicate any activities that go beyond the standard ones, which are also undertaken by the competitors (e.g. for pushchairs, EN 1888 European safety standard; for carrycots for babies, the latest ECE 40-44 European standard and authorisation of marketing and use in road traffic, OekoTex Standard 100plus quality mark, which is awarded to fabric that is free of harmful substances and environmentally friendly, and includes: Oeko-Tex Standard 100, a mark awarded to materials free of pollution and harmful substances, and Oeko-Tex Standard 1000 (environmentally friendly production that is based on sustainable sewage disposal and energy consumption)),

2) Activities connected with business investments, which, according to the respondent, lead to the company's development and growth. According to the respondent, it is worth mentioning the construction of a modern production hall, energy-saving lighting and logistics transport solutions. 
The research showed that company $\mathrm{Y}$, despite a large number of employees (almost 150), did not undertake any social activities, such as additional support for its employees and their families, social assistance or cultural support. The company lacks activities promoting integration of its employees.

\section{Summary}

The review of the literature shows that activities aimed at implementation of sustainable development principles in organisations' ongoing activities are widespread, but they mostly result from legal regulations and existing standards in the European Union. However, this refers to profit-oriented companies, often in the manufacturing and services sectors. The research conducted enabled comparison of activities aimed at implementing sustainable development principles in selected areas of organisations' ongoing activities. As the main objectives of activity are by definition different in the organisations researched, it was found that the willingness to implement SD principles resulted not only from the mission, vision and main objectives of the organisations, but also from changes in their business environment, customer expectations, and SDoriented leadership.

Both the respondents expressed the need to adopt the culture of sustainable development in the activities of their organisations, perceived the concept of sustainable development in the same way, but they took different actions. In the case of the non-profit organisation, most important was SD-oriented leadership and the social dimension of stakeholders' expectations. In the case of the for-profit organisation, environmentally-friendly activities are undertaken if they are translated into the economic aspect and profit. The research has confirmed that for profit-oriented organisation it is mainly economic factors that constitute an argument in favour of implementation of such solutions.

As the author of the research was interested in additional, non-obligatory, commitment to the issue addressed in the paper, it has been found that the organisations used different ways to put into action the declaration of the implementation of sustainable development principles in ongoing activities. Based on the case study research conducted in the end of 2017 and in the beginning of 2018, it can be concluded that Housing Cooperative $\mathrm{X}$ is a leader in implementation of SD principles in ongoing activities, combining three aspects constituting the pillars of the idea of sustainable development: economic, social and environmental dimensions. On the other hand, quite interestingly and surprisingly, manufacturing enterprise $\mathrm{Y}$ does not show willingness to develop in the direction of implementation of sustainable development principles, and no SD-oriented leadership exists in this case.

The research has shown that there are still huge differences in organisations' activities, which result from knowledge and timeless solutions, which can be attributed to managers, chairpersons, company owners and often whole families. Thus, it turns out that knowledge on the implementation of sustainable development principles in business environment is needed and should be continuously propagated.

The author hopes for continuation of the research on a bigger group of organisations and expanding on the research problem, in order to find out relationships and formulate recommendations for flexible management of organisations. 


\section{References}

Annan-Diab, F. \& Molinari, C. (2017). Interdisciplinarity: Practical approach to advancing education for sustainability and for the Sustainable Development Goals. The International Journal of Management Education, 15(2), B, 73-83, https://doi.org/10.1016/j.ijme.2017.03.006.

Avsec, R. \& Štromajer, J. (2015). Development and socioeconomic environment of cooperatives in Slovenia. Journal of Co-operative Organization and Management, 3(1), 40-48, https://doi.org/10.1016/j.jcom.2015.02.004.

Baumgartner, R. J. \& Rauter, R. (2017). Strategic perspectives of corporate sustainability management to develop a sustainable organization. Journal of Cleaner Production, 140(1), 81-92, https://doi.org/10.1016/j.jclepro.2016.04.146.

Bhandari, G., Bliemel, M., Harold, A. \& Hassanein, K. (2004). Flexibility in e-Business Strategy: A Requirement for Success. Global Journal of flexible Systems Management, 5, 11-22.

Brzozowski, T. T. (2010). Koncepcja zrównoważonego rozwoju wyzwaniem dla procesów transformacji przemysłu i usług. Prace Komisji Geografii Przemystu, 15, Warszawa-Kraków, 219-228.

Caldera H. T. S., Desha C. \& Dawes L. (2018). Exploring the characteristics of sustainable business practice in small and medium-sized enterprises: Experiences from the Australian manufacturing industry. Journal of Cleaner Production, 177, 338-349. DOI: 10.1016/j.jclepro.2017.12.265.

Cingöz A. \& Akdoğan A. A. (2013). Strategic flexibility, environmental dynamism, and innovation performance: An empirical study. Procedia - Social and Behavioral Sciences, 99, 582-589, DOI: 10.1016/j.sbspro.2013.10.528.

Dvořáková, L. \& Zborková, J. (2014). Integration of Sustainable Development at Enterprise Level, Procedia Engineering, 69, 686-695, DOI: 10.1016/j.proeng.2014.03.043.

Hyršlová, J. (2009). Úcetnictuí udř̌itelného rozuoje podniku. Praha: VŠEM.

Ivanová, E., Lemańska-Majdzik, A. (2017). Comparison of the Quality of the Business Environment in the Slovak Republic and Poland. Vadyba-Journal of Management, 1(30), 21-33.

Katsuhiko, Sh. \& Hitt, A. (2004). Strategic flexibility organizational preparedness to reverse ineffective strategic Decisions. Academy of Management Executive, 18(4), 44-59.

Kiron, D., Unruh, G., Kruschwitz, N., Reeves, M., Rubel, R., Meyer Zum Felde, A. (2017). Corporate Sustainability at a Crossroads. Progress Toward Our Common Future in Uncertain Times. (2018, March 10). Retrieved from https://sloanreview.mit.edu/projects/corporate-sustainability-at-acrossroads/

Lemańska-Majdzik A. (2013). Conception of a housing association management shown based on the example of „Północ” housing association in Częstochowa. In A. Lemańska-Majdzik \& P. Tomski (Eds.), Challenges in Contemporary Management (pp. 72-83). Częstochowa: Sekcja Wydawnictw Wydziału Zarządzania Politechniki Częstochowskiej.

Lemańska-Majdzik, A., Okręglicka, M. \& Gorzeń-Mitka, I. (2016). Selected Development Factors of Small and Medium Enterprises. In 28th International Business Information Management Association Conference (28th IBIMA), Vision 2020: Innovation Management, Development Sustainability and Competitive Economic Growth, Sevilla, Spain, 9-10 November 2016, 1090-1099.

Lozano, R. (2015). A holistic perspective on corporate sustainability drivers. Corporate Social Responsibility and Environmental Management, 22, (1), 32-44, https://doi.org/10.1002/csr.1325.

Melkonyan, A., Gottschalk, D. \& Vasanth Kamath V. P. (2017). Sustainability assessments and their implementation possibilities within the business models of companies. Sustainable Production and Consumption, 12, 1-15, https://doi.org/10.1016/j.spc.2017.04.001.

Nawaz, W. \& Koç, M. (2018). Development of a systematic framework for sustainability management of organizations. Journal of Cleaner Production, 171, 1255-1274, https://doi.org/10.1016/j.jclepro.2017.10.011.

Okręglicka, M., Mynarzová, M. \& Kaňa, R. (2015). Business Process Maturity in Small and Medium Sized Enterprises. Polish Journal of Management Studies, 12(1), 121-131.

Oliveira Neto, G. C., Leite, R. R., Shibao, F. Y. \& Lucato, W. C. (2017). Framework to overcome barriers in the implementation of cleaner production in small and medium-sized enterprises: Multiple case studies in Brazil. Journal of Cleaner Production, 142, 50-62, DOI: 10.1016/j.jclepro.2016.08.150. 
Purtik, H., Zimmerling, E. \& Welpe, I. M. (2016). Cooperatives as catalysts for sustainable neighborhoods a qualitative analysis of the participatory development process toward a 2000-Watt Society. Journal of Cleaner Production, 134, Part A, 112-123, https://doi.org/10.1016/j.jclepro.2016.02.075.

Roberts N. \& Stockport G. J. (2009). Defining Strategic Flexibility. Global Journal of Flexible Systems Management, 10(1), 27-32, https://doi.org/10.1007/BF03396553.

Sanchez, R. (1995). Strategic flexibility in product competition. Strategic Management Journal, 16(5), 135-159, https://doi.org/10.1002/smj.4250160921.

Seidel, M., Seidel, R., Tedford, D., Cross, R., Wait, L. (2008). A systems modeling approach to support environmentally sustainable business development in manufacturing SMEs. World Academy of Science, Engineering and Technology, 48, 121-129, https://doi.org/10.1002/csr.1343.

Sipa, M. (2017). Innovation as a Key Factors of Small Business Competition. European Journal of Sustainable Development, 6(1), 344-356, DOI: 10.14207/ejsd.2017.v6n1p344.

Sroufe, R. (2017). Integration and organizational change towards sustainability. Journal of Cleaner Production, 162, 315-329, https://doi.org/10.1016/j.jclepro.2017.05.180.

Sustainability's strategic worth: McKinsey Global Survey results 2014. (2018, March 11). Retrieved from https://www.mckinsey.com/business-functions/sustainability-and-resource-productivity/ourinsights/sustainabilitys-strategic-worth-mckinsey-global-survey-results.

Tamayo-Torres, I., Ruiz-Moreno, A. \& Verdú, A. J. (2010). The moderating effect of innovative capacity on the relationship between real options and strategic flexibility. Industrial Marketing Management, 39, 1120-1127, https://doi.org/10.1016/j.indmarman.2009.10.003.

Trojanowski, T. (2015). Przedsiębiorstwa wobec wyzwań zrównoważonego rozwoju. Zeszyty Naukowe Politechniki Ślaskiej, Seria: Organizacja I Zarzadzanie, 77, 239-247.

Ussahawanitchakit, P. \& Sriboonlue, P. (2011). Transformational leadership, strategic flexibility, learning capability, continuous improvement, and firm performance: Evidence from Thailand. International Journal of Business Strategy, 11(1), 162-172,

Ustawa z dnia 15 grudnia 2000 r. O spótdzielniach mieszkanionych. Dz. U. z 2018 r. poz. 582, (Act of 15 December 2000 on Housing cooperatives. Journal of Laws of 2018, item 582).

Ustawa z dnia 16 września 1982 r. Prawo spótdzielcze. Dz.U. 1982 nr 30 poz. 210, (Act of 16 September 1982, Law on cooperatives. Journal of Laws of 1982, item 210). 